\title{
Wykaz Prac Profesor Aleksandry Jewtuchowicz
}

\section{Monografie}

1. Efekty zewnętrzne w procesach urbanizacji i uprzemysłowienia, Acta Universitatis Lodziensis, Łódź 1987, ss. 215.

2. Terytorium i współczesne dylematy jego rozwoju, Wyd. Uniwersytetu Łódzkiego, Łódź 2005, ss. 216.

\section{Redakcja naukowa prac zbiorowych}

1. Développement local i régional dans la période de transformation de l'économie polonaise (Rozwój lokalny i regionalny w okresie transformacji gospodarki polskiej), Wyd. Uniwersytetu Łódzkiego, Łódź 1993, wersja francuska i polska.

2. Terytorialne i ekologiczne aspekty rozwoju gospodarczego, Folia Oeconomica z. 143, Wyd. Uniwersytetu Łódzkiego, Łódź 1997.

3. Środowisko przedsiębiorczości, innowacje a rozwój terytorialny, Wyd. Uniwersytetu Łódzkiego, Łódź 1997, s. 126.

4. Strategiczne problemy rozwoju miast i regionów, Wyd. Uniwersytet Łódzki, Zakład Ekonomiki Regionalnej i Ochrony Środowiska, Łódź 2000 .

5. Strategiczne problemy rozwoju regionów w procesie integracji europejskiej, Wyd. Uniwersytet Łódzki, Zakład Ekonomiki Regionalnej i Ochrony Środowiska, Łódź 2001, s. 249.

6. Zewnętrzne determinanty rozwoju innowacyjnych firm, Wyd. Katedra Ekonomii Uniwersytetu Łódzkiego, Monografie, Rozprawy, Raporty, Opracowania, Łódź 2001, s. 339 (współredakcja z K. Matusiakiem i E. Stawaszem).

7. Struktury i procesy kształtujące łódzki region społeczno-gospodarczy, Wyd. Uniwersytet Łódzki, Zakład Ekonomiki Regionalnej i Ochrony Środowiska, Łódź 2002, s. 361 (współredakcja z A. Suliborskim).

8. Wiedza, innowacyjność, przedsiębiorczość a rozwój regionów, Wyd. Uniwersytetu Łódzkiego, Łódź 2004, s. 504. 
9. Przestrzenne zróżnicowanie procesów transformacji społeczno-gospodarczej w regionie łódzkim, Wyd. Uniwersytetu Łódzkiego, Łódź, 2006, s. 358 (współredakcja z A. Suliborskim).

10. Region w gospodarce opartej na wiedzy, Wyd. Uniwersytetu Łódzkiego, Łódź, 2007, s. 288.

11. Współczesne wyzwania miast i regionów, Wyd. Uniwersytetu Łódzkiego, Łódź 2009, s. 321, (współredakcja z A. Rzeńca).

12. Łódzka metropolia. Problemy integracji gospodarczej, Wyd. Biblioteka, Łódź 2010, s. 217 (współredakcja z M. Wójcikiem).

13. Terytorialny wymiar procesów innowacji i przedsiębiorczości. Studia polsko - francuskie (Innovation et entrepreneuriat: quels enjeux territoriaux? Analyses croisées franco-polonaises), Wyd. Uniwersytetu Łódzkiego, Łódź 2012, (współredakcja z G. Duché, A. Nowakowska, C. Peyroux).

\section{Artykuły}

1. Wpływ siły roboczej na rozwój regionu cieszyńskiego, [w:] Wpływ czynnika ludzkiego na wzrost gospodarczy, Wyd. Uniwersytetu Łódzkiego, Łódź 1975, (współautorstwo z J. Niedomagała).

2. Einfluz der Investitionstätigkeit der Industriebe auf die Entwiclung der Infrastruktur der Städte (Wpływ działalności inwestycyjnej zakładów przemysłowych na rozwój infrastruktury miast), [w:] Territoriale Aspekte der Grundfondswirtschaft und der Investitionspolitik, Berlin 1977.

3. Siła robocza w województwie łódzkim jako czynnik rozwoju przemysłu, Zeszyty Naukowe Uniwersytetu Łódzkiego, Nauki Ekonomiczne, Nr 7/1977.

4. Niektóre problemy ochrony środowiska naturalnego człowieka na przykładzie Tomaszowskich Zakładów Włókien Sztucznych „Chemitex-Wistom" w Tomaszowie Mazowieckim, Studia Regionalne, t.II, PWN, Warszawa 1978.

5. Infrastruktura społeczna Skierniewic w świetle opinii ich mieszkańców, [w:] Funkcja woj. skierniewickiego leżącego między dwiema rozwiniętymi aglomeracjami miejsko-przemysłowymi, z. 91, TUP, Łódź 1979 (współautorstwo z J. Regulskim).

6. Wpływ inwestycji socjalnych przemysłu na rozwój infrastruktury społecznej miast, [w:] Rola przemysłu w rozwoju miast i miasto jako baza działalności przemysłowej, Wyd. Uniwersytetu Łódzkiego, Łódź 1979. 
7. Przestrzenne zróżnicowanie warunków bytowych ludności (na przykładzie wybranych miast), Studia Regionalne, t. III, PWN, Warszawa 1980.

8. Wpływ zakładów przemysłowych na poprawę warunków bytowych ludności miejskiej, [w:] Gospodarka przestrzenna a warunki bytowe ludności, Biuletyn KPZK PAN, z.115, Warszawa 1981, s. 95-167.

9. Podstawy metodologiczne rachunku społeczno - ekonomicznego sieci i jednostek osadniczych, Biuletyn IGiPZ PAN, z. 34, Warszawa 1981 (współautorstwo z J. Regulskim).

10. Pojęcie i mierniki warunków bytowych ludności, [w:] Gospodarka przestrzenna a warunki bytowe ludności, Biuletyn KPZK PAN, z.115, Warszawa 1981, s. 30-51.

11. Korzyści zewnętrzne jako czynnik kształtowania zachowań zakładów przemysłowych, [w:] Gospodarka przestrzenna a warunki bytowe ludności, Biuletyn KPZK PAN z.115, Warszawa 1981, s. 186-192.

12. L'importance des effets externes dans l'accroissement régional, [w:] Croissance et développement régional, Université de Montpellier III 1982, s. 117-132.

13. L'industrie et l'organisation spatiale en presence d'effets externes d'agglomeration dans l'économie planifiée, Cahiers de CERVE, Paris 1983.

14. Wpływ efektów zewnętrznych na zachowania przestrzenne przedsiębiorstw przemysłowych, Studia i Materiały COMSE, t.47, Poznań 1983.

15. Społeczno-ekonomiczne konsekwencje uprzemysłowienia miast a korzyści zewnętrzne lokalizacji, Wyd. Uniwersytetu Łódzkiego, z. 37, Łódź 1984.

16. Effets externes et organisation de l'espace dans le processus d'industrialisation, [w:] Modes de production, Espace et Sociétés, Université de Montpellier III, Montpellier 1984. s. 332-345.

17. Thèorie d'externalités et pratique de planification spatiale en Pologne, [w:] Planning Theory in Practice, Actes du colloque, Turyn 1986.

18. Efekty urbanizacyjne a problemy lokalizacji działalności przemysłowej, [w:] Problemy urbanizacji w Polsce i na Świecie , Wyd. Akademii Ekonomicznej we Wrocławiu, Wrocław 1986. s. 137-148.

19. Rozwój miast, uprzemysłowienie i efekty zewnętrzne, Acta Universitatis Lodziensis, Łódź 1987, s. 7-19.

20. Principes et objectifs de la planification spatiale en Pologne, [w:] Planning issues in Italy and Poland, Documenti Universita di Catania, no 10, Catania 1987. 
21. Influence des investissements des entreprises industrielles sur les structures spatiales des villes, [w:] Piano Paesistico e Piano Urbanistico, Documenti Universita di Catania, no 12, Catania 1988.

22. Les facteurs exogènes et endogènes du développement des systèmes locaux. Réflexions sur les recherches du groupe Languedoc-Mazowsze, [w:] Valeur de l'espace et développement local, Université Montpellier III, Montpellier 1988.

23. Problèmes de gestion des systèmes territoriaux locaux, [w:] Etudes Régionales et Locales, Université de Varsovie, Warszwa 1989, s. $147-160$.

24. La gestion des systèmes teritoriaux, Association Internationale pour les Statistiques Régionales et Urbaines, 1989.

25. Efekty zewnętrzne w systemach lokalnych. Rozwój gospodarki lokalnej w teorii i praktyce, Wyd. Akademii Ekonomicznej w Poznaniu, Poznań 1990, s. 148-164, (współautorstwo z T. Markowskim).

26. Les externalités, leur création et leur rôle dans le développement local, Cahiers d'Economie Appliquée aux Sciences Humaines (CEASH) nr 13, Université Paul Valéry, Montpellier 1990, s. 1-18.

27. La localisation de nouvelles activités et la transformation de l' espace urbain, Cahiers d'Economie Appliquée aux Sciences Humaines (CEASH) nr 15, Université Paul Valéry, Montpellier 1992, s. 25-44.

28. Les conditions de la création et du développement des PME en Pologne, Revue Internationale PME, Vol. 5, No 1, Quebec 1992, s. 43-62.

29. Le rôle et l'importance économique de PME dans la restructuration de l'économie polonaise, [w:] La Transition en Pologne, Cahiers d'Economie Appliquée aux Sciences Humaines (CEASH) nr 16, Université Paul Valéry, Montpellier 1993, s. 63-80.

30. Zakres i rola informacji w rozwoju lokalnym i regionalnym, [w:] Modelowanie organizacji i systemy informatyczne w gospodarce regionu, pod red. Z. Dowgiałło, Urząd Wojewódzki w Szczecinie, Instytut Badań Systemowych PAN, Szczecin 1993, s. 67-79.

31. Orientations générales et principaux problèmes de la restructuration de Lodz et sa voïvodie (Podstawowe kierunki i problemy restrukturyzacji Łodzi i Województwa Łódzkiego), [w:] Développement local et régional dans la période de transformation de l'économie polonaise (Rozwój lokalny i regionalny w okresie transformacji gospodarki polskiej), pod red. A. Jewtuchowicz, Wyd. Uniwersytetu Łódzkiego, Łódź 1993, s. 64-92 (wersja polska i francuska).

32. Ekonomiczne i przestrzenne problemy rozwoju obszarów chronionych, [w:] Modelowanie gospodarki w regionach szczególnie chronionych, pod red. B. Krawca, Instytut Badań Systemowych PAN, Szczecin 1994, s. 141-158 (współautorstwo z W. Wiśniewską). 
33. Les déterminants régionaux et locaux de la restructuration de l'industrie polonaise, Cahiers Franco-Polonais no 11-12, Grenoble 1994, s. 9-22 (współautorstwo z M.Horbaczewska).

34. Restrukturyzacja regionalna i formy pomocy w rozwoju małych i średnich przedsiębiorstw w Polsce (w aspekcie zmian strukturalnych w Europie Zachodniej na przykładzie Francji), [w:] Uwarunkowania rozwoju sektora MSP w krajach Centralnej i Wschodniej Europy, pod red. B. Piaseckiego i Z. Koniecznego, Wyd. Uniwersytetu Łódzkiego, Łódź 1995, s. 47-62.

35. Strategie rozwoju dużych miast i ich wpływ na proces transformacji gospodarki, [w:] Strategie rozwoju wielkich miast, pod red. R. Domańskiego, Biuletyn KPZK, z. 169, Warszawa 1995. s. 83-102.

36. Problemy powstawania środowiska przedsiębiorczości i lokalnych systemów produkcyjnych, [w:] Rozwój i restrukturyzacja gospodarki regionalnej, Wyd. Akademii Ekonomicznej w Krakowie, Kraków 1996.

37. Środowisko przedsiębiorczości a rozwój terytorialny, [w:] Zarządzanie rozwojem gminy w zespołach miejsko - przemysłowych, Wyd. PTE w Katowicach, Katowice 1996, s. 110-118.

38. Rozwój lokalnej przedsiębiorczości a restrukturyzacja gospodarki, [w:] Gospodarka, przestrzeń, środowisko, pod red. U. Wich, Wyd. Uniwersytetu Marii Curie-Skłodowskiej, Lublin 1996, s. 349-360.

39. Powstawanie środowiska przedsiębiorczości i sieci innowacji. Teorie i rzeczywistość, [w:] Ośrodki innowacji i przedsiębiorczości w Polsce, Wyd. SOOIPP, Poznań 1996, s. 49-58.

40. Dynamika rozwoju terytorialnego a procesy restrukturyzacji gospodarczej, [w:] Aktualne problemy gospodarki lokalnej, pod red. A. Zalewskiego, Monografie i opracowania, nr 414, SGH, Warszawa 1996, s. 55-66.

41. Entrepreneuriat et développement des entreprises et stratégie de développement locale et régionale, [w:] Restructuration des entreprises dans les économies en transition, Wyd. AE w Poznaniu, Poznań 1997, s. 239-253.

42. Rozwój terytorialny a strategie lokalizacyjne przedsiębiorstw, [w:] Terytorialne i ekologiczne aspekty rozwoju gospodarczego, Wyd. Uniwersytetu Łódzkiego, Folia Oeconomica, z. 143, Łódź 1997, s. 5-19.

43. Przedsiębiorczość, innowacje i konkurencyjność regionów (podstawowe pojęcia i identyfikacja problemów), [w:] Środowisko przedsiębiorczości, innowacje a rozwój terytorialny, Wyd. Uniwersytetu Łódzkiego, Łódź 1997, s. 9-18.

44. Conditions institutionnelles du développement territorial dans le processus de transformation économique, [w:] L'organisation du 
développement territorial dans les pays en transition, Ed. Centre de Manegement pour les pays de l'Est, Université Pierre Mendès Grenoble, Grenoble 1998, s. 74-85 (współautorstwo z D. Taverne).

45. Polityka technologiczna i organizacja transferu technologii we Francji, [w:] Przedsiębiorczość i transfer technologii. Polska perspektywa, pod red. K.B. Matusiak, E. Stawasz, Wyd. Katedra Ekonomii Uniwersytetu Łódzkiego, Żyrardowskie Stowarzyszenie Wspierania Przedsiębiorczości, Łódź-Żyrardów 1998, s. 233-258.

46. Ochrona krajobrazu w polityce rozwoju gminy, [w:] Sterowanie ekorozwojem, Zarządzanie w warunkach ekorozwoju, pod red. B. Poskrobko, t.II, Wyd. Politechniki Białostockiej, Białystok 1998, s. 243-251 (współautorstwo z N. Joachimiak).

47. Les sytèmes productifs locaux et les milieux innovateurs à la lumière des nouvelles conceptions sur le developpement local et régional, [w:] Milieu entrepreneurial, innowation et développement territorial, Cahiers d'Economie Appliquée aux Sciences Humaines (CEASH) nr 17, Université Paul Valéry, Montpellier 1998, s. 3-17.

48. Rola instytucji w tworzeniu środowisk przedsiębiorczości. Przykład Łodzi, [w:] Gospodarka, przestrzeń, środowisko, pod red. S. L. Bagdzińskiego i M. Marszałkowskiej, Wyd. Uniwersytetu Mikołaja Kopernika, Torun 1998, s. 373-383.

49. Infrastruktura przedsiębiorczości i transferu technologii w Polsce, [w:] Instrumenty i narzędzia transferu technologii i polityki innowacyjnej państwa, Agencja Techniki i Technologii, materiały z seminarium, Warszawa 1998, (współautorstwo z K.B. Matusiak).

50. La perspective de la Pologne de l'intégration avec l'Union Européenne, [w:] Politique en question; questions aux politiques, Ed. Cercles Condorcet, Toulouse 1999, s. 28 - 40.

51. Problèmes de développement des petites et moyennes entreprises dans les stratégies de développement régional (exemple de Lodz), Cahiers d'Economie Appliquée aux Sciences Humaines (CEASH) nr 18, Université Paul Valéry, Montpellier 1999, s. 3-18.

52. Conditions institutionnelles du développement territorial dans le processus de transformation économique, Cahiers d'Economie Appliquée aux Sciences Humaines (CEASH) nr 18, Université Paul Valéry, Montpellier 1999, s. 31-46 (współautorstwo z D. Taverne).

53. Terytorialne systemy produkcyjne - nowy model rozwoju lokalnego i regionalnego, [w:] Strategiczne problemy rozwoju miast i regionów, pod red. A. Jewtuchowicz, Wyd. Uniwersytetu Łódzkiego, Zakład Ekonomiki Regionalnej i Ochrony Środowiska, Łódź 2000.

54. Les conditions de création d'un milieu entrepreunarial et innovant dans la politique de développement local et régional (exemple de la 
région de Lodz), [w:] Dialogues culturels et développement économique européenn, Ed. Sedcom Libris, Iasi 2000, s. 255-264.

55. Innowacje i organizacja transferu technologii jako elementy konkurencyjności regionu, [w:] Polityka regionalna i jej rola w podnoszeniu konkurencyjności regionów, pod red. M. Klamut i L. Cybulskiego, Wyd. Akademii Ekonomicznej im. Oskara Langego we Wrocławiu, Wrocław 2000, s. 119-127.

56. Rola infrastruktury przedsiębiorczości i transferu technologii w podnoszeniu konkurencyjności regionów, [w:] Konkurencyjność gospodarcza regionu w warunkach nowego ustroju terytorialno-administracyjnego, pod red. W. Kosiedowskiego, Wyd. Uniwersytetu Mikołaja Kopernika w Toruniu, Włocławskie Towarzystwo Naukowe, Torun 2000, s. 59-71 (współautorstwo z W. Kosiedowskim).

57. Kontrakty planowe państwa z regionem we Francji, [w:] Strategiczne problemy rozwoju regionów w procesie integracji europejskiej, pod red. A. Jewtuchowicz, Wyd. Uniwersytetu Łódzkiego, Zakład Ekonomiki Regionalnej i Ochrony Środowiska, Łódź 2001, s.48-59.

58. Problèmes de développement du réseau et du milieu innovateur - théorie et réalité (l'exemple de la Pologne), [w:] La Pologne. Ses transformations économiques et institutionnelles et le processus de son intégration à l'Union européenne, Ed. Université Paul Valéry Montpellier III, Montpellier 2001, s. 293-313.

59. Strategie przedsiębiorstw innowacyjnych - współpraca czy konkurencja?, [w:] Konkurencyjność podmiotów gospodarczych w procesie integracji i globalizacji, Zeszyty Naukowe Politechniki Poznańskiej, Organizacja i Zarządzanie, Nr 32, Poznań 2001, s. 196-204.

60. Terytorium i lokalne systemy produkcyjne a globalizacja gospodarki, [w:] Gospodarka i polityka regionalna okresu transformacji, pod red. W. Kosiedowski, Wyd. Uniwersytetu Mikołaja Kopernika, Toruń 2001, s. 37-54.

61. Rozwój, środowisko, sieci innowacyjne i lokalne systemy produkcyjne, [w:] Zewnętrzne determinanty rozwoju innowacyjnych firm, pod red. K. Matusiak, E. Stawasz, A. Jewtuchowicz, Wyd. Katedra Ekonomii Uniwersytetu Łódzkiego, Monografie - Rozprawy - Raporty - Opracowania, Łódź 2001, s. 69-95.

62. Rozwój sieci i innowacyjnego środowiska przedsiębiorczości, [w:] Zewnętrzne determinanty rozwoju innowacyjnych firm, pod red. K. Matusiak, E. Stawasz, A. Jewtuchowicz, Wyd. Katedra Ekonomii Uniwersytetu Łódzkiego, Monografie - Rozprawy - Raporty Opracowania, Łódź 2001, s. 69-95.

63. Innowacyjność środowisk przedsiębiorczości, [w:] Konkurencyjność miast i regionów a przedsiębiorczość i przemiany strukturalne, pod 
red. A. Klasik, Prace Naukowe Akademii Ekonomicznej im. K. Adamieckiego w Katowicach, Katowice 2001, s. 115-126.

64. Compétitivité et stratégies de développement des régions polonaises dans les conditions de l'intégration européenne, Revista de Economia e Direito Galileu, UAL, vol. VII, nr 1, Lizbona 2002, s. 53-71.

65. Les dilemmes du développement des régions polonaises, [w:] La construction européenne. Modes de développement et partenaires, Faculté Des Sciences Economiques l’Université Matej Bel, Bańska Bystrzyca 2002, s. 32-45.

66. The behaviour of innovative enterprises in Poland, [w:] Regiona konkuretspeja, Daugavpils Univeritates, DU izdevnieciba, vol. II, Ed. Saule, Ryga 2002, s. 58-65.

67. Конкурентоспособность и стратегии развития польских регионов в условиях европейской интеграции, [in:] Белорусский экономический журнал, nr 3 (20), Mińsk, 2002, s. 100-107.

68. Środowiska przedsiębiorczości a problem spójności gospodarki regionu, [w:] Struktury i procesy kształtujące łódzki region społeczno-gospodarczy, pod red. A. Jewtuchowicz, A. Suliborski, Wyd. Uniwersytetu Łódzkiego, Łódź 2002.

69. Współpraca i budowanie sieci powiązań między aktorami gospodarczymi i społecznymi regionu, [w:] Struktury i procesy kształtujace łódzki region społeczno-gospodarczy, pod red. A. Jewtuchowicz, A. Suliborski, Wyd. Uniwersytetu Łódzkiego, Łódź 2002.

70. Création de la société civile - enjeu du développement régional du XXI siècle (réflexions sur le développement et le comportement des institutions régionales), [w:] L' innovation dans l'europe elargie, Ed. Académie Economique D.A. Tsenov de Svishtov, l'Université Pierre Mendès France de Grenoble, Bulgaria 2003.

71. Rozwój terytorialny - teoria a polska rzeczywistość (przykład regionu łódzkiego), [w:] Zarządzanie rozwojem lokalnym i regionalnym w kontekście integracji europejskiej, pod red. A. Klasika, Biuletyn KPZK PAN, z. 208, Warszawa 2003, s. 9-29 (współautorstwo z I. Pietrzyk).

72. Procesy metropolizacji a perspektywy rozwoju przestrzeni europejskiej, [w:] Obszary metropolitalne a rozwój regionalny i lokalny, pod. red. K. Szołka i A. Zakrzewskiej-Półtorak, Wyd. Akademii Ekonomicznej we Wrocławiu, Biblioteka Regionalistyki, nr 4(1/2004), Wrocław 2004, s. 51-61.

73. Budowanie społecznych podstaw polityki rozwoju regionalnego - refleksje na temat działalności regionalnych instytucji wspierajacych rozwój, [w:] Przedsiębiorczość i innowacyjność małych i średnich przedsiębiorstw - wyzwania współczesności, pod. red. A. Kalety, 
K. Moszkowicz, L. Woźniaka, Wyd. Akademii Ekonomicznej im. Oskara Langego we Wrocławiu, Wrocław 2004, s. 188-195.

74 Budowa konkurencyjności regionów. Rozważania na temat dynamiki rozwoju terytorialnego, [w:] Gospodarka lokalna i regionalna w teorii i praktyce, pod red. R. Brol, Wyd. Akademii Ekonomicznej im. Oskara Langego we Wrocławiu, Wrocław 2004, s. 350-359.

75. Miasta w rozwoju regionów. Ewolucja relacji: miasto-region, [w:] Konkurencyjność i potencjał rozwoju polskich metropolii - szanse i bariery, pod red. S. Korenika i K. Szołka, Biuletyn KPZK PAN, z. 214, Warszawa 2004, s. 96-103.

76. Region w łódzkich naukach ekonomicznych, [w:] Mistrzowie i szkoły łódzkiej ekonomii i socjologii. Szkice do portretu Wydziału Ekonomiczno-Socjologicznego Uniwersytetu Łódzkiego, Wyd. Uniwersytetu Łódzkiego, Łódź 2005, s. 101-111.

77. Le rôle des institutions dans la création du milieu entrepreunarial et dans le transfert des technologies et d'innovations en Pologne, [w:] La creazione di imprese innovative e le esperienze di spin-off universitari nell'Europa allargata, Ed. Università degli Studi di Perugia, Seria Monografie, Perugia 2005, s. 309-317.

78. Globalne uwarunkowania rozwoju lokalnego. Rozważania na temat glokalizacji, [w:] Gospodarka - zarządzanie - przestrzeń, pod red. T. Markowski, D. Stawasz, Acta Universitatis Lodziensis, Folia Oeconomica nr 186, Wyd. Uniwersytetu Łódzkiego, Łódź 2005, s. $33-49$.

79. Conditions institutionnelles du développement territorial dans le processus de transformation économique, [in:] Pologne 1989-2004. La longue marche, C. Martin (ed.), La Librairie des Humanités, L'Harmattan, Paris 2005 (współautorstwo D. Taverne).

80. Création de la société civile: enjeu du développement régional du XXIe siècle, [in:] Pologne 1989-2004. La longue marche, C. Martin (ed.), La Librairie des Humanités, L’Harmattan, Paris 2005 (współautorstwo D. Taverne).

81. Innowacje i strategie przedsiębiorstw. Analiza sytuacji MSP w regionie łódzkim, [w:] Polska w rozszerzonej Unii Europejskiej - uwarunkowania i perspektywy rozwoju, pod red. M. Klamut, E. Szostak, Prace Naukowe Akademii Ekonomicznej im. Oskara Langego we Wrocławiu, nr 1071, Wrocław 2005, s. 75-85.

82. Dilemmas of the regional policy in Poland. Deliberations on the role of institutions and establishing relationships based on partnership in the region, [w:] The development of polish social and economic space at the beginning of the 21 st century (chosen aspects), 
S. Korenik (ed.), Polish Academy of Sciences, Commitee for Spatial and Regional Planning, Warszawa 2006, s. 14-27.

83. Territoire en tant qu'acteur du processus de développement. Remarques sur la concurrence et la compétitivité territoriale (exemple de la région de Lodz), [in:] La dynamique des ressources humaines - facteur potentiel d'integration dans l'Europe élargie, Ed. L'Université de l'Ouest Timisoara, Timisoara 2006, s. 287-297.

84. Terytorium, terytorializacja, rozwój regionalny, [w:] Przedsiębiorczość i konkurencyjność a rozwój regionalny, pod red. A. Klasika, Prace Naukowe Akademii Ekonomicznej w Katowicach, Katowice 2006, s. 164-176.

85. Strategie dużych firm a proces terytorializacji - wprowadzenie metodologiczne, [w:] Przedsiębiorczość i konkurencyjność a rozwój regionalny, pod red. A. Klasika, Prace Naukowe Akademii Ekonomicznej w Katowicach, Katowice 2006, s. 155-163 (współautorstwo z A. Nowakowską i Z. Przygodzkim).

86. Globalne uwarunkowania rozwoju regionalnego, [w:] Przestrzenne zróżnicowanie procesów transformacji społeczno-gospodarczej w regionie łódzkim, pod red. A. Jewtuchowicz, A. Suliborski, Wyd. Uniwersytetu Łódzkiego, Łódź 2006, s. 15-26.

87. Procesy transformacji społeczno-gospodarczej w regionie łódzkim, [w:] Przestrzenne zróżnicowanie procesów transformacji społeczno-gospodarczej w regionie łódzkim, pod red. A. Jewtuchowicz, A. Suliborski, Wyd. Uniwersytetu Łódzkiego, Łódź 2006, s. 343-358 (współautorstwo z A. Suliborskim).

88. Determinants globaux du developpement local: processus de transformations en Pologne apres 1990 (exemple de la region de Lodz), [in:] L'Europe et le developpement regional. Politiques communautaires, entrpreneuriat et mobilisation de la societe civile, PGV/ AESIC ISLA-Lisboa, Lizbona 2007, s. 296 - 301.

89. Terytorium jako podstawa procesu tworzenia innowacyjnych środowisk przedsiębiorczości [w:] Budowanie zdolności innowacyjnych regionów, pod red. A. Nowakowska, Wyd. Biblioteka, Łódź 2009 , s. 9-17.

90. Territoire en tant qu'acteur du processus de développement. Remarques sur la concurrence et la compétitivité territoriale (exemple de la région de Lodz), Management \& Gouvernance, Entreprises - Territoires - Sociétés, Cahiers Scientifiques Internationaux du réseau PGV, nr 1, 2009, s. 65-79.

91. Kształtowanie się funkcji gospodarczych Łodzi do 1918 roku, [w:] Łódź. Monografia miasta, pod red. S. Liszewski, T I, rozdz. 4, Łódzkie 
Towarzystwo Naukowe, Łódź 2009, str. 125-159 (współautorstwo z A. Suliborskim, wersja polska i angielska).

92. Życie społeczne i kulturalne w Łodzi do 1918 r., [w:] Łódź. Monografia miasta, pod red. S. Liszewski, T I, rozdz. 4, Łódzkie Towarzystwo Naukowe, Łódź 2009, str. 160-168 (współautorstwo z A. Suliborskim, wersja polska i angielska).

93. Struktura gospodarcza Łodzi w latach 1918-1989, [w:] Łódź. Monografia miasta, pod red. S. Liszewski, T I, rozdz. 4, Łódzkie Towarzystwo Naukowe, Łódź 2009, str. 297-322 (współautorstwo z A. Suliborskim, wersja polska i angielska).

94. Życie społeczne i kulturalne w Łodzi w latach 1918-1989, [w:] Łódź. Monografia miasta, pod red. S. Liszewski, T I, rozdz. 4, Łódzkie Towarzystwo Naukowe, Łódź 2009, str. 323-364 (współautorstwo z A. Suliborskim, wersja polska i angielska).

95. Gospodarka Łodzi na przełomie XX i XXI wieku, [w:] Łódź. Monografia miasta, pod red. S. Liszewski, T I, rozdz. 4, Łódzkie Towarzystwo Naukowe, Łódź 2009, str. 400-409 (współautorstwo z A. Suliborskim, wersja polska i angielska).

96. Życie kulturalne Łodzi na przełomie XX i XXI wieku, [w:] Łódź. Monografia miasta, pod red. S. Liszewski, T I, rozdz. 4, Łódzkie Towarzystwo Naukowe, Łódź 2009, str. 410-418 (współautorstwo z A. Suliborskim, wersja polska i angielska).

97. Edukacja w zakresie gospodarki przestrzennej - bilans 12 lat doświadczeń Wydziału Ekonomiczno-Socjologicznego w Łodzi, [w:] Poprawa jakości i efektywności planowania i zarządzania rozwojem $\mathrm{w}$ administracji publicznej. Wyzwania wobec kształcenia na kierunku gospodarka przestrzenna, pod red. T. Kudłacz, T. Markowski, Biuletyn KPZK PAN, z. 244, Warszawa 2010, s. 122-132 (współautorstwo z A. Rzeńcą).

98. Gospodarcze podstawy rozwoju metropolii, [w:] Łódzka metropolia. Problemy integracji gospodarczej, pod red. A. Jewtuchowicz, M. Wójcik, Wyd. Biblioteka, Łódź 2010, s. 11-21.

99. Znaczenie metropolii w rozwoju gospodarczym, [w:] Polska i europejska polityka gospodarcza wobec wyzwań XXI wieku, pod red. Ewa Pancer-Cybulska, Wyd. Uniwersytetu Ekonomicznego we Wrocławiu, Wrocław 2012, s. 244-257.

100. Współpraca polsko-francuska w rozwoju łódzkiej szkoły badań regionalnych, [w:] Terytorialny wymiar procesów innowacji i przedsiębiorczości. Studia polsko - francuskie, pod red. A Jewtuchowicz, G. Duché, A. Nowakowska, C. Peyroux, Wyd. Uniwersytetu Łódzkiego, Łódź 2012. 
101. Współzarządzanie rozwojem lokalnym - rozważania na temat governance, [w:] Terytorialny wymiar procesów innowacji i przedsiębiorczości. Studia polsko - francuskie, pod red. A Jewtuchowicz, G. Duché, A. Nowakowska, C. Peyroux, Wyd. Uniwersytetu Łódzkiego, Łódź 2012.

102. Terytorium i jego rozwój w warunkach globalizacji, [w:] Globalizacja i regionalizacja we współczesnym świecie, pod red. E. Molendowski, Wyd. Uniwersytetu Ekonomicznego w Krakowie, Kraków 2012, s. 23-33.

\section{Najważniejsze projekty naukowo-badawcze}

- Bariery $w$ gospodarczym i przestrzennym rozwoju miast i regionów projekt realizowany w ramach Centralnego Programu Badań Podstawowych (CPBP 03.12.02.); 1986-1990, kierownik projektu;

- Rozwój regionalny - rozwój lokalny - samorzad terytorialny - projekt realizowany w ramach Centralnego Programu Badań Podstawowych (CPBP 09.8); 1986-1990, kierownik projektu;

- Tworzenia lokalnych warunków rozwoju dla małych i średnich przedsiębiorstw - program badawczy polsko-francuski realizowany z Uniwersytetem Montpellier III; 1990-1994, kierownik projektu;

- Tworzenie środowiska przedsiębiorczości $w$ Łodzi $i$ regionie łódzkim - program badawczy polsko-francuski realizowany z Uniwersytetem Montpellier III; 1995-1999, kierownik projektu;

- Determinanty powstawania i rozwoju przedsiębiorstw innowacyjnych, projekt KBN, nr 1 H02C 049 17; 1999-2001, główny wykonawca projektu;

- Mechanizmy tworzenia się tódzkiego regionu społeczno-gospodarczego po reformie administracyjnej państwa, projekt KBN, nr $1 \mathrm{H} 02 \mathrm{C} 052$ 19; 2000-2002; kierownik projektu;

- EU Enlargement and Multi-Level Governance in the European Regional and Environmental Policies: Patterns of Institutional Learning and Europeanisation among Cohesion Countries (Greece, Ireland and Portugal) and Lessons for New Members (Hungary and Poland), project 5 Programu Ramowego UE ADAPT; 2000-2002, koordynator badań;

- Przedsiębiorczość i konkurencyjność a rozwój regionalny, projekt KBN, nr 2 H02C 022 25; 2003-2005, główny wykonawca projektu;

- Zróżnicowanie przestrzenne procesów transformacji społeczno-gospodarczej $w$ regionie tódzkim, projekt MNiSZW nr 1 H02C 002 26; 2004-2005, kierownik projektu; 
- Regionalna Strategia Innowacji dla Województwa Łódzkiego LORIS PLUS, projekt realizowany w ramach 6 Programu Ramowego UE; 2007-2008, główny wykonawca projektu;

- Budowanie zdolności innowacyjnych polskich regionów, projekt MNiSZW, nr 1867/H03/2007/32; 2007-2009, główny wykonawca projektu;

- Procesy integracji i dezintegracji $w$ Łódzkim Obszarze Metropolitalnym projekt MNiSZW, nr 0513/B/H03/2008/35; 2008-2010, kierownik projektu badawczego;

- Polityka i narzędzia kreowania kapitału ludzkiego $w$ regionie, projekt MNiSZW, nr NN 114 183938; 2010-2012, główny wykonawca projek$\mathrm{tu}$;

- Ocena skuteczności regionalnych systemów dystrybucji funduszy strukturalnych Unii Europejskiej dla podnoszenia konkurencyjności i innowacyjności matych $i$ średnich przedsiębiorstw. Studium porównawcze województwa tódzkiego i regionu Umbrii (Wtochy), projekt NCN, nr NN114 143240; 2011 - 2014, główny wykonawca projektu;

- Funkcjonowanie lokalnych systemów produkcyjnych $w$ warunkach kryzysu gospodarczego (analiza porównawcza $i$ benchmarking $w$ wybranych krajach UE oraz krajach trzecich), projekt 7 Ramowego Programu Komisji Europejskiej, nr FPT.PEOPLE - 2011. IRSES; nr 295050; 2012 - 2015; kierownik projektu;

\section{Członkowstwo w instytucjach i organizacjach naukowych}

1. Association de Science Régionale de Langue Française - ASRDLF (od 1992).

2. Un reseau de Laboratoires Europeens associant des Pays d'Europe Occidentale et des Pays du Groupe de Vysegrad - PGV (od 1994).

3. Regional Science Association - RSA (od 1992).

4. Komitet Przestrzennego Zagospodarowania Kraju przy Prezydium PAN (1993-1998).

5. Komisje Komitetu Przestrzennego Zagospodarowania Polskiej Akademii Nauk:

- Komisja Gospodarki Przestrzennej i Rozwoju Regionalnego (1981-1990);

- Komisja Infrastruktury Osadniczej (1984-1990);

- Komisja Obszarów Miejskich (1990-1992);

- Zespół Problemowy ds. Kształcenia i Rozwoju Kadr z zakresu gospodarki przestrzennej (2011-2014).

6. Łódzkie Towarzystwo Naukowe (od 1991). 
7. Włocławskie Towarzystwo Naukowe (od 2000).

8. Towarzystwo Urbanistów Polskich (od 1974).

9. Europejskie Stowarzyszenie Ekonomistów Środowiska i Zasobów Naturalnych; Oddział Polski (od 1994).

10. Międzynarodowa Akademia Nauk Organizacji i Zarządzania, członek założyciel Sekcji Polskiej (od 2001).

11. Członek Rady Społeczno-Gospodarczej przy Radzie Narodowej Miasta Łodzi (1987-1989).

12. Członek Rady Naukowej Fundacji Inkubator (od 2001).

\section{Nagrody}

- Nagroda Ministra Administracji, Gospodarki Terenowej i Ochrony Środowiska za prace „Wpływ szkodliwości przemysłu na naturalne środowisko człowieka na przykładzie Zakładów Włókien Chemicznych 'Chemitex-Wistom' w Tomaszowie Mazowieckim”, 1975;

- Nagroda Ministra Nauki, Szkolnictwa Wyższego i Techniki za prace doktorska „Wpływ przedsiębiorstw przemysłowych na poprawe warunków życia ludności miejskiej wybranych województw"; nagroda indywidualna III stopnia, 1979;

- Nagroda Wojewody Piotrkowskiego za prace doktorska „Wpływ przedsiębiorstw przemysłowych na poprawę warunków życia ludności miejskiej wybranych województw”, 1979;

- Nagroda Rektora Uniwersytetu Łódzkiego za cykl prac dotyczacych istoty efektów zewnętrznych oraz ich wpływu na funkcjonowanie systemów społecznych; nagroda indywidualna III stopnia, 1987;

- Nagroda Rektora Uniwersytetu Łódzkiego za prace habilitacyjna „Efekty zewnętrzne w procesach urbanizacji i uprzemysłowienia”, 1988;

- Nagroda Rektora Uniwersytetu Łódzkiego za osiągnięcia dydaktyczne, wychowawcze i organizacyjne, indywidualna drugiego stopnia, 1989;

- Nagroda Ministra Nauki i Szkolnictwa Wyższego za książkę „Terytorium i współczesne dylematy jego rozwoju", 2006;

- Nagroda Prezydenta Miasta Łodzi za pracę „Łódź - monografia miasta"; nagroda zespołowa, 2010;

- Nagroda Rektora Uniwersytetu Łódzkiego za dwutomowa publikacje pt. „Budowanie zdolności innowacyjnych regionów” i „Zdolności innowacyjne polskich regionów"; nagroda zespołowa III stopnia, 2010;

- Nagroda Prezydenta Miasta Łodzi za dwutomowa prace „Łódzka metropolia. Problemy integracji gospodarczej” i „Łódzka metropolia. 
Problemy integracji społecznej i przestrzennej"; nagroda zespołowa, 2011 ;

- Nagroda Rektora Uniwersytetu Łódzkiego za dwutomowa prace „Łódzka metropolia. Problemy integracji gospodarczej” i „Łódzka metropolia. Problemy integracji społecznej i przestrzennej"; nagroda zespołowa III stopnia, 2011;

- Nagroda Rektora Uniwersytetu Łódzkiego za osiagnięcia dydaktyczne, wychowawcze i organizacyjne, 2012;

\section{Odznaczenia}

- Złota Odznaka Uniwersytetu Łódzkiego, 1994;

- Srebrny Krzyż Zasługi, 2003;

- Medal „Uniwersytet Łódzki w Służbie Społeczeństwu i Nauce”, 2004;

- Medal Komisji Edukacji Narodowej, 2006;

- Medal Złoty za Długoletnią Służbę, 2008;

\section{Promocje prac doktorskich}

1. Nina Joachimiak, Wptyw obrotu ziemia na przemiany struktury agrarnej (na przyktadzie województwa piotrkowskiego); praca obroniona na Wydziale Ekonomiczno-Socjologicznym Uniwersytetu Łódzkiego, wrzesień 1993.

2. Aleksandra Nowakowska, Polityka i strategia rozwoju gminy w okresie transformacji systemowej (na przyktadzie gmin województwa tódzkiego); praca obroniona na Wydziale Ekonomiczno-Socjologicznym Uniwersytetu Łódzkiego, grudzień 1998.

3. Monika Słupińska, Regionalna polityka wspierania innowacyjności matych i średnich przedsiębiorstw; praca obroniona na Wydziale Ekonomiczno-Socjologicznym Uniwersytetu Łódzkiego, luty 2001.

4. Cezary Brzeziński, Polityka rozwoju polskich regionów w warunkach integracji europejskiej; praca obroniona na Wydziale Ekonomiczno-Socjologicznym Uniwersytetu Łódzkiego, grudzień 2002.

5. Zbigniew Przygodzki, Środowiska przedsiębiorczości jako warunek konkurencyjności regionów; praca obroniona na Wydziale Ekonomiczno-Socjologicznym Uniwersytetu Łódzkiego, czerwiec 2004.

6. Jacek Chądzyński, Lokalne systemy produkcyjne - mechanizmy powstawania i bariery rozwoju; praca obroniona na Wydziale Ekonomiczno-Socjologicznym Uniwersytetu Łódzkiego, czerwiec 2005. 
7. Mariusz Sokołowicz, Region wobec procesów globalizacji - terytorializacja przedsiębiorstw międzynarodowych (na przyktadzie regionu tódzkiego); praca obroniona na Wydziale Ekonomiczno-Socjologicznym Uniwersytetu Łódzkiego, listopad 2006.

8. Agnieszka Rzeńca, Polityka rozwoju gminy na obszarach prawnie chronionych (przyktad gmin województwa tódzkiego, na terenie których utworzono park krajobrazowy); praca obroniona na Wydziale Ekonomiczno-Socjologicznym Uniwersytetu Łódzkiego, maj 2007.

9. Marcin Feltynowski, Skuteczność polityki przestrzennej na terenach wiejskich (na przykładzie gmin województwa tódzkiego), praca obroniona na Wydziale Ekonomiczno-Socjologicznym Uniwersytetu Łódzkiego, czerwiec 2008.

10. Zofia Dolewka, Modernizacja administracji samorzadowej $w$ gminach województwa tódzkiego $w$ kontekście norm $i$ standardów międzynarodowych, praca obroniona na Wydziale EkonomicznoSocjologicznym Uniwersytetu Łódzkiego, grudzień 2008.

11. Beata Wieteska - Rosiak, Bezpieczeństwo publiczne jako czynnik konkurencyjności regionu, praca obroniona na Wydziale Ekonomiczno-Socjologicznym Uniwersytetu Łódzkiego, czerwiec 2010.

\section{Otwarte przewody doktorskie}

1. Ewa Boryczka, Procesy rewitalizacji $i$ ich konsekwencje dla przekształceń bazy ekonomicznej miasta. Przyktad miast poprzemystowych, przewód otwarty w kwietniu 2011.

2. Marek Wojciechowski, Koszt funkcjonowania władzy $i$ administracji samorzadowej, przewód otwarty, przewód otwarty w czerwcu 2011.

3. Ewelina Kina, Technologie informacyjno-komunikacyjne $w$ ksztattowaniu lokalnego kapitału społecznego, przewód otwarty we wrześniu 2012.

4. Anna Tomaszewska, Polityka rozwoju społeczeństwa informacyjnego w polskich regionach, przewód otwarty w kwietniu 2013. 